\title{
Language Planning for "Mundurukú do Amazonas"
}

\section{Planejamento Linguístico para "Mundurukú do Amazonas"}

Gessiane Picanço*

Universidade Federal do Pará

Belém - Pará / Brasil

ABSTRACT: Mundurukú, a Tupian language of Brazil, exhibits two opposite scenarios. On one extreme, there is Mundurukú do Pará, the language of daily communication in the Mundurukú Indigenous Land, with fluent speakers found across all generations and still acquired by children as a mother tongue. On the other extreme, there is Mundurukú do Amazonas, formerly spoken in the KwatáLaranjal Indigenous Land, but whose inhabitants have shifted to Portuguese. A group of Mundurukú students from Amazonas decided to initiate a process of language revitalisation as a way to strengthen the community's ethnic and cultural identity. This paper reports the initial stages of language planning, and includes future actions to promote language use in the homes and communities, assessement of language proficiency, and definition of educational programs to teach Mundurukú in local schools.

KEYWORDS: Mundurukú do Amazonas, language revitalisation, language planning, language policy, indigenous education, language teaching, orthography.

RESUMO: Mundurukú, uma língua Tupí do Brasil, apresenta dois cenários opostos. Em um extremo, há o Mundurukú do Pará, a língua de comunicação diária na Terra Indígena Mundurukú, com falantes fluentes de todas as idades e adquirida pelas crianças como língua materna. No outro extremo encontra-se o Mundurukú do Amazonas, Terra Indígena Kwatá-Laranjal, que foi substituída pelo Português. Um grupo de estudantes Mundurukú do Amazonas decidiu iniciar um processo de revitalização de sua língua, como uma forma de fortalecer a identidade étnica e cultural da comunidade. Este trabalho relata os estágios iniciais do planejamento linguístico, incluindo as açōes futuras para promover o uso da língua em casa e na comunidade, avaliação da proficiência na língua e definiçāo de programas educacionais para ensinar Mundurukú nas escolas locais.

PALAVRAS-CHAVE: Mundurukú do Amazonas, revitalização de língua, planejamento linguístico, política linguística, educação indígena, ensino de língua, ortografia.

* picanco.g@hotmail.com 


\section{Introduction}

This paper reports the initial stages of the development of a communityand school-based language planning for teaching "Mundurukú do Amazonas". It is the result of intensive meetings that happen in February and early August, 2011. ${ }^{2}$ The meetings aimed at establishing goals and future actions for language revitalization in the Kwatá-laranjal Indigenous Land, in Amazonas. These goals include assessment of language proficiency, definition of goals and strategies to promote language use at home and in the community, development of school-based language programs, and, finally, literacy planning.

Mundurukú is a Tupian language of many Mundurukú communities in Brazil. Its entire population is mainly distributed to three states in Brazil: Mato Grosso, Amazonas and Pará, with the larger groups concentrated in Pará and Amazonas. ${ }^{3}$

\section{TABLE 1}

Mundurukú population

\begin{tabular}{l|c|c|r}
\hline \multicolumn{1}{c|}{ State } & $\begin{array}{c}\text { Number } \\
\text { of villages }\end{array}$ & $\begin{array}{c}\text { Approximate population } \\
\text { per village }\end{array}$ & Total \\
\hline Amazonas & 60 & 1 to 500 residents & 3,820 \\
Pará & 80 & 2 to 700 residents & 7,643 \\
Mato Grosso & 4 & 5 to 110 residents & 167 \\
\hline & & & 11,630 \\
\hline
\end{tabular}

Source: FUNASA, 2010.

The two geographic areas with the highest number of inhabitants are shown in the map below in FIG. 1. One is Kwatá-Laranjal, located in the city of Borba, in the state of Amazonas, and the other is the Mundurukú Sai Cinza

\footnotetext{
${ }^{1}$ This study was partially supported by the Ambassadors' Fund for Cultural Preservation-USA. I am grateful to all Mundurukú communities who kindly collaborated with it.

${ }^{2}$ Two days in February and eight consecutive days in August; the meetings took all day long.

${ }^{3}$ The Fundação Nacional de Saúde - FUNASA - census refers to the Mundurukú living population in certified Indigenous Lands or in small towns in three states listed in TAB. 1. The information about the Munduruku population in other cities in Brazil is not available.
} 
Indigenous Lands, in Jacareacanga, in the neighbor state of Pará. I will refer to these areas as "Mundurukú do Amazonas" and "Mundurukú do Pará", respectively. The two groups are also known as "Mundurukú do Madeira" and "Mundurukú do Tapajós", in reference to the rivers that cross the regions.

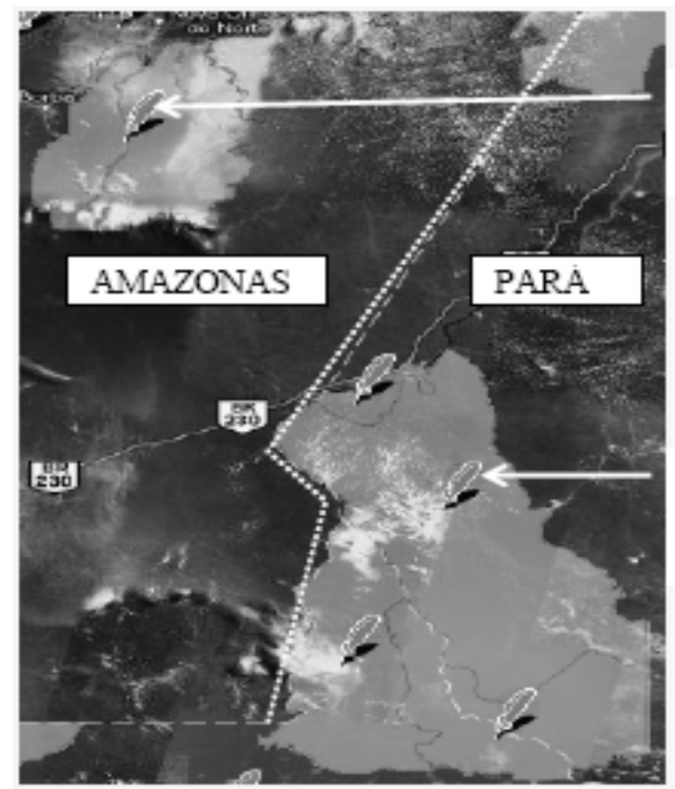

\section{T.I. Kwatá- \\ Laranjal \\ (Amazonas)}

T.I.

Mundurukú

(Pará)

FIGURE 1 - Mundurukú Indigenous Lands in the states of Amazonas and Pará. Source: Retrieved from: <http://pib.socioambiental.org>.

It is not only the geographical distance that separates the population; language and culture also contrast. Munduruku has the status of being the language of daily communication within some villages in the state of Pará; it is learned by children as a mother tongue, and fluent speakers are found across all generations, including monolingual speakers, typically elders, women, and children. However, the number of bilingual individuals is rapidly increasing and more and more they become equally competent in both Munduruku and Portuguese. ${ }^{4}$

\footnotetext{
${ }^{4}$ For example, an entire Mundurukú community located in Itaituba in the state of Pará, and very close to the Mundurukú Land, has already shifted to Portuguese.
} 
The Pará community still maintains a few former traditions, in particular those related to fishing with "timbó" (fish poison), hunting for game animals, and growing crops in collective gardens. They also preserve some narratives and songs, which have to do with daily situations and nature in general, in addition to the making handicrafts such as baskets and necklaces.

In contrast, Mundurukú language and culture are no longer active in the region of Kwatá-Laranjal, at least for the past five decades. With the exception of seven elders, all above the age of 80 , the younger generations have shifted to the national language Portuguese (BORELLA; SANTOS, 2011). Along with the loss of the language, the authors also point out other consequences such as cultural decline, ethnic detachment, division of the community, and, above all, having their indigenous heritage questioned by non-Indians. In this respect, the Mundurukú language has become the most important element to corroborate the community's identity. "Strengthening the community's ethnic and cultural identity" is the major reason the community gives to revive the Mundurukú language.

Revitalization initiatives have first emerged during an educational program developed in the region, the "Kabia'ra Project", which took place between 1999 and 2002.5 At that time, the project could still rely on elder speakers, who were invited to participate in some classes to talk about their ancestors' history (BELEZA, 2002). For some time after, the elders continued to visit local schools to pass on aspects of their language and culture to children, a practice done casually, that is, without any assistance by the project, and which stopped because of the elders' poor health conditions (BORELLA; SANTOS, 2011).

The existence of thousands of fluent speakers in the state of Pará is certainly a great advantage to language revitalization in the region of Kwatá-Laranjal. It is their hope to maintain regular contact, and even expect a few of them to move to each other's land, though temporarily, as language learners for the "Mundurukú do Amazonas", or as language teachers for the "Mundurukú do Pará". There are still some economic factors working against their expectations, as traveling requires further expenses and funding that are not available to them. Eight young speakers from Pará, aged between 20 and $30,{ }^{6}$ go to Amazonas twice a year to attend to

\footnotetext{
${ }^{5}$ The project was associated to the Pira-yawara Educational Program for Indigenous Teachers, implemented by the Secretaria Estadual de Educação (SEDUC-AM).

${ }^{6}$ Two female are nearly monolingual speakers of Mundurukú.
} 
an educational program that is currently developed by the Faculdade de Educação (FACED) of the Universidade Federal do Amazonas (UFAM [Federal University of Amazonas]). It is a 5-year (2011-2015) Program called "Licenciatura Intercultural para Formação de Professores Indígenas-Turma Mundurukú”, and is under the coordination of professors from UFAM; classes take place in Borba, a town near the Kwatá-Laranjal region, three months a year. The program's primary goal is to train teachers, though not language teachers in particular. The inclusion of the Mundurukúlanguage in the curriculum, as well as the participation of students from the state of Pará, was requested by the community as an attempt to expand language use in Kwatá-Laranjal. In total a group of 45 Mundurukú students is involved, including the ones from the state of Pará. Although the speakers from Pará are not trained language instructors, and are participating in the program as regular students, their contributions are crucial to achieve the goal of revitalizing the indigenous language and culture.

It is in this scenario that the Mundurukú students and I began to develop language planning activities for the community. I was invited by the UFAM group to participate as a linguist expert in Mundurukú, a language that I have been working on for the past 15 years. My role in the program was to provide practical support for the language program in local schools, help to develop the curriculum, give assistance in language teacher training, and work on the development of school-based learning resources. The next sections describe the outcomes of our preliminary work.

\section{Language use and vitality in Kwatá-Laranjal}

Determining language use and vitality in a community must be a priority in a revitalization program (CRYSTAL, 2000; GRENOBLE; WHALEY, 2006). It is essential to evaluate the number of fluent speakers, their age groups, and how many young adults speak and use their language (GRIMES, 2000; HINTON, 2001; GRENOBLE; WHALEY, 2006). Two language surveys were performed to assess the degree of language proficiency and use in Kwatá-Laranjal. Eneida Gonzaga dos Santos and Cristina Borella, members of the UFAM program, carried out a sociolinguistic survey, between September and October 2010.7 They

\footnotetext{
7 Relatório do Levantamento Sociolinguístico do Povo Mundurukú, FACED/UFAM, Manaus-AM, February, 2011. The survey was based on a questionnaire, but the authors do not give details of the questions included in it.
} 
interviewed 292 adults from 27 villages in the Kwatá-Laranjal Indigenous Land. The results showed that the entire community has seven elders who can still speak Mundurukú (SANTOS; BORELLA, 2011). These elders are the ones who can carry on and understand a conversation in the native language; two elders live in the Laranjal village, four in Kwatá, and one in Kaiowé, but make no use of the native language on a daily basis. ${ }^{8}$ As for the others, about 32 Munduruku are familiar with common words and fossilized phrases, but cannot produce any new sentences or follow the details of a conversation; their knowledge of Mundurukú was obtained later in life or as young adults, and is never really used for communication. The other interviewees are individuals who know nothing about the language, except for a few words. According to Borella and Santos (2011), the use of Mundurukú in the villages is limited to greetings; in any other situation, Portuguese is the preferred language.

Language death in region of Kwatá-Laranjal appears to be the case of an abrupt language shift. Beleza (2002) reports that few years after introducing Portuguese to the community, supposedly as a peace-making effort, nonindigenous teachers encouraged the remaining Mundurukú individuals to abandon their language, treating it as a low prestige language. The community had already been reduced to a small group because of outbreaks of some diseases, and so offered no resistance to the process of language shifting. Based on the elders' testimony (BELEZA, 2002), the last generation to have fully acquired the Mundurukú language seems to be now above the age of 80 . There may be other categories such as terminal speakers or rememberers (CRAIG, 1997), but these ones have not been identified to this point.

During our meetings, a self-assessment of language proficiency was performed with the students. The activity gave them a chance to evaluate their own knowledge of Mundurukú, in addition to identifying a specific level of proficiency they want to achieve, and what kind of skill would be necessary to become a more fluent speaker. In a proficiency continuum, from fluent speakers, semi-speakers to non-speakers (e.g., DORIAN, 1977, 1981; SCHMIDT, 1985), all students are non-speakers, as is the majority of the Mundurukú people. However, any modest skill some may have of their

\footnotetext{
${ }^{8}$ Santos and Borella (2011) report that the elders rarely visit each other because of age and health problems. I interviewed and recorded data from one of the elders, Ms. Ester Cardoso, 92 years old. She mentioned that she has had the opportunity to hold long conversations with visitors from the state of Pará.
} 
language is a further motivation to improve language use in the community. That is the reason why the four options below were presented for selfassessment:

\section{Categories for language proficiency}

(i) I speak Mundurukú fluently and maintain formal and informal conversations on any topic.

(ii) I nderstand spoken Mundurukú but have difficulty to maintain conversations, especially about non-familiar topics.

(iii) I understand only some phrases and words in a conversation about familiar topics, but cannot follow the details of it and cannot speak anything.

(iv) I do not understand or speak anything in Mundurukú; I know only a couple of isolated words.

Among the students from the state of Amazonas, 23 selected option (iii), and 12 selected (iv); two other students missed the meeting that day. Among the ones from the state of Pará, seven chose option (i), and one chose (ii). This last one was a girl who lived part of her childhood in a Portuguesespeaking environment, returning to the village as a teenager; she's now in her 20's. According to her, she can understand conversations on almost any topic, but has limitations expressing herself in the language. The activity helped them to set an important goal: to get closer to or achieve at least category (ii). In other words, they could estimate where they are now and where they want to be in five years.

${ }^{9}$ Each option was previously explained to the participants. The actual Portuguese sentences were:

(i) "Eu falo Mundurukú sem nenhuma dificuldade e consigo manter conversas formais e informais sobre qualquer assunto."

(ii) "Eu consigo entender o que é dito em Mundurukú, mas tenho dificuldade para manter uma conversa, especialmente sobre assuntos fora do meu ambiente familiar."

(iii) "Eu consigo entender umas poucas frases e palavras em uma conversa quando é sobre um assunto do meu ambiente familiar, mas eu não consigo acompanhar todos os detalhes dessa conversa e nem consigo falar nada na língua."

(iv) "Eu não entendo nem falo nada em Mundurukú; eu sei somente algumas palavras soltas." 
Following the same scale, the students were then asked to evaluate people's knowledge of Munduruku in their communities. The assessment was meant to show the value of intergenerational transmission; even those who know a few words and sentences were not making use of them so that the younger an individual is, the less she / he knows about the Munduruku language. The age groups were established as follows: ${ }^{10}$
Language proficiency by age groups
Group 1: children (up to 12 years old)
Group 2: teenagers and young adults (from 13 to about 25)
Group 3: adults (from 26 to about 49)
Group 4: middle-aged adults (from 50 to about 80)
Group 5: elders (above 80)

According to the students' judgments, groups 1 and 2 (children, teenagers and young adults) may know some isolated words (category (iv)) referring mostly to animals and plants (e.g. daydo 'armadillo', axima 'fish', akoba 'banana', etc.). Groups 3 and 4 were classified as both (iii) and (iv), with the majority of adults in (iv), and middle-aged adults in (iii); elders vary between categories (ii) and (iii), except for seven fluent speakers, placed in category (i). ${ }^{11}$ While adults may have some knowledge of Mundurukú, younger generations have not acquired anything. In fact, language use is restricted to greetings such as kabia 'good morning', wuykat 'good afternoon', and xipat 'good / thank you'; everything else is spoken in Portuguese. The assessment of language proficiency and communicative abilities helped students have a clear definition of what their goals and future actions should be, as well as their responsibility in intergenerational transmission. I believe

\footnotetext{
${ }^{10}$ Mundurukú villages have a population ranging from 2 to 500 residents interacting on a daily basis. I assume they are aware of the language situation within their communities. Of course this is not to say that their judgment is absolutely accurate, as already observed for other languages (e.g. Dorian 1977, 1981). However, the purpose of the task was to show them that learning Mundurukú will do nothing for the community if they do not teach younger generations.

${ }^{11}$ It is still necessary to gather detailed information from Mundurukú elders. The sociolinguistic survey is not clear about the interviewees' ages, but it seems that they were mostly under the age of 50 .
} 
they are now alert to the fact that, even having limited knowledge of Mundurukú, successful revival depends on them sharing it. In this sense, informal self-evaluations of language skills may be a good stimulus for language use. It gives people self-confidence, and helps them to see the need to improve whichever knowledge they may have to.

\section{Determining goals and strategies}

After discussing language proficiency and use in the community, the students began to identify their goals. They established three priorities, listed as major goals:

Major goals for language planning of Mundurukú

1) to teach Mundurukú language and culture to youth groups in schools;

2) to encourage language use in the communities to keep language alive; and

3) to preserve ethnic identity by restoring former customs and traditions.

It should be noted that the Kwatá-Laranjal residents do not want Mundurukú become the community's primary language. Given its "prestige", the replacement of Portuguese is, therefore, not under discussion. The idea is to implement a program that will increase language awareness and guarantee its continuity.

Similarly, the initial phase in the acquisition plan does not involve a decision between full and partial fluency, just some knowledge of Mundurukú to help people interact at least on specific domains. This approach has contributed to a better response to language lessons, making the learning process more pleasant and, possibly, with a greater chance of success.

Alongside the setting out of major goals, planning considered the types of language learning activities to promote the use of Munduruku at home and within the community. Different strategies were suggested:

Strategies

- To promote community meetings to discuss the importance of using Mundurukú.

- To organize weekend events to show former traditions (e.g., dance and songs).

- To use Mundurukú daily and in all places, even if one knows only some words and phrases. 
- To put up cards in Mundurukú identifying objects and places for youth groups.

- To record songs and stories with elders to be used in schools.

- To promote language learning through past cultural traditions, plays, songs, poetry, and story-telling sessions.

- To have more frequent contact with the Mundurukú do Pará.

As a class activity, the students put into practice some of the strategies they would do in the community. There were several demonstrations of how to get local residents involved (by talking to them), how to use the language Mundurukú in everyday situations, how to prepare traditional food and artefacts using Mundurukú words, as well as demonstrations of child plays, with the help of some Mundurukú children who were accompanying their parents. Language lessons also included common commands ("Come here!", "Go outside!”, “Give me some fish / a banana...”, “Stand up!”, “Sit down!”, and so on), and short dialogues (introducing people and oneself, for example). All these activities were based on oral and interactive skills, but these were their top priority to develop language programs for children, in order to include them in schools, and develop appropriate teaching materials.

\section{Literacy planning and standardization of Mundurukú orthography}

The Munduruku believe that the schools must also be the settings for primary revitalization activities, giving children the opportunity to appreciate and learn their language and culture through both speaking and writing. Some teachers have already started teaching Mundurukú on their own. However, lack of language materials and proper training works against their efforts to get students develop communicative skills in Mundurukú.

One major factor is the writing system. Both "Mundurukú do Pará" and "Mundurukú do Amazonas" have existing orthographic systems, and both exhibit problems. The first practical orthography was developed for "Mundurukú do Pará", by Marjorie Crofts of the Summer Institute of Linguistics, and is also the most popular amongst the population. It is composed of 17 letters for consonants and five letters for vowels, with one letter per phoneme. 


\section{[1] Mundurukú inventory and alphabet, based on Marjorie Crofts' proposal}

\begin{tabular}{|c|c|c|c|c|c|c|c|}
\hline Vowels & \multicolumn{2}{|c|}{ Front } & Central & Back & & & \\
\hline High & $\begin{array}{l}\text { ii/ } \\
\mathrm{i}\end{array}$ & $\begin{array}{l}/ \tilde{\mathrm{i}} / \\
\tilde{\mathrm{i}} \\
\end{array}$ & & & & & \\
\hline Mid & & $\begin{array}{l}\tilde{\mathrm{e}} / \\
\tilde{\mathrm{e}} \\
\end{array}$ & $\begin{array}{cc}/ \mathrm{\partial} / & / \tilde{\partial} / \\
\mathrm{u} & \tilde{\mathrm{u}} \\
\end{array}$ & $\mid \begin{array}{cc}/ \mathrm{o} / & / \tilde{\mathrm{o}} / \\
\mathrm{o} & \tilde{\mathrm{o}}\end{array}$ & & & \\
\hline Low & & & $\begin{array}{cc}/ \mathrm{a} / & / \tilde{a} / \\
\mathrm{a} & \tilde{\mathrm{a}}\end{array}$ & & & & \\
\hline Consonar & & Bila & bial & Alveolar & Palatal & Velar & Glottal \\
\hline Stops & & & $\begin{array}{c}\mathrm{b} / \\
\mathrm{b}\end{array}$ & $\begin{array}{cc}\mathrm{t} / & / \mathrm{d} / \\
\mathrm{t} & \mathrm{d} \\
\end{array}$ & $\begin{array}{|cc|}/ \mathrm{t} f / & / \mathrm{d} / \\
\mathrm{c} & \mathrm{j} \\
\end{array}$ & $\begin{array}{l}\mid \mathrm{k} / \\
\mathrm{k}\end{array}$ & 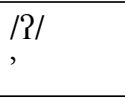 \\
\hline Nasals & & & $\begin{array}{c}/ \mathrm{m} / \\
\mathrm{m}\end{array}$ & $\begin{array}{c}/ \mathrm{n} / \\
\mathrm{n}\end{array}$ & & $\begin{array}{l}/ \mathrm{y} / \\
\tilde{\mathrm{g}}\end{array}$ & \\
\hline Fricatives & & & & & $\begin{array}{l}/ S / \\
\mathrm{x}\end{array}$ & & $\begin{array}{l}/ \mathrm{h} / \\
\mathrm{h}\end{array}$ \\
\hline Approxin & ants & & $\begin{array}{c}/ \mathrm{w} / \\
\mathrm{w}\end{array}$ & $\begin{array}{c}/ \mathrm{r} / \\
\mathrm{r}\end{array}$ & $\begin{array}{l}/ j / \\
y\end{array}$ & & \\
\hline
\end{tabular}

However, the Mundurukú phonology has complexities that are not orthographically represented. In addition to nasality, the language also distinguishes modal and creaky vowels, leading to an inventory with four series: oral and nasal modal vowels, and oral and nasal creaky vowels (PICANÇO, 2005). The modal-creaky series are presented here; creaky voice is indicated by a tilde placed under the vowel (v).

[2] Series of vowels (see PICANÇO, 1997)

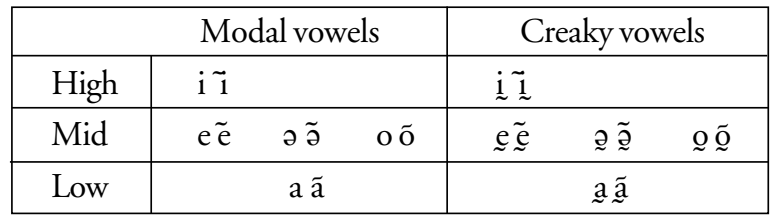

The following pairs illustrate the modal-creaky contrasts, and how the words are orthographically represented. ${ }^{12}$

\footnotetext{
${ }_{12}$ Pointed brackets $<\ldots>$ stand for orthographic examples, while slashes /.../ stand for phonological examples.
} 
[3]

\begin{tabular}{|c|c|c|c|}
\hline (a) & $\begin{array}{l}\text { /wida/ } \\
\text { /wida/ }\end{array}$ & $\begin{array}{l}<\text { wida }> \\
<\text { wida }>\end{array}$ & $\begin{array}{l}\text { 'clay' } \\
\text { 'jaguar' }\end{array}$ \\
\hline (b) & $\begin{array}{l}\text { /ḑededem/ } \\
\text { /idedem/ }\end{array}$ & $\begin{array}{l}<\text { jededem }> \\
<\text { idedem }>\end{array}$ & $\begin{array}{c}\text { 'to play an instrument' } \\
\text { 'to grate' }\end{array}$ \\
\hline (c) & 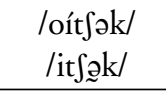 & $\begin{array}{l}<\text { oicuk> } \\
<\text { icuk }>\end{array}$ & $\begin{array}{l}\text { 'It broke.' } \\
\text { 'It's cold.' }\end{array}$ \\
\hline (d) & $\begin{array}{l}/ \text { dat } / \\
/ \text { dat } /\end{array}$ & $\begin{array}{l}<\text { dat }> \\
<\text { dat }>\end{array}$ & $\begin{array}{l}\text { 'scorpion' } \\
\text { 'vomit' }\end{array}$ \\
\hline (e) & $\begin{array}{l}\text { /irore/ } \\
\text { /ierore/ }\end{array}$ & $\begin{array}{l}<\text { irore> } \\
<\text { ierore> }\end{array}$ & $\begin{array}{l}\text { 'It's loose.' } \\
\text { 'It's ripe.' }\end{array}$ \\
\hline
\end{tabular}

Vowels also contrast for tones, but only modal vowels may surface on a High or Low tone; creaky vowels are restricted to Low tone (PICANÇO, 2005). The examples in (4) illustrate words that differ only in tone, either $\mathrm{H}$ or L. Phonologically, $\mathrm{H}$ tone is marked by acute accent and $\mathrm{L}$ tone is unmarked.

[4]

\begin{tabular}{|c|c|c|c|c|}
\hline (a) & $\begin{array}{l}\text { lél } \\
\text { lel }\end{array}$ & $\begin{array}{l}{[\mathrm{H}]} \\
{[\mathrm{L}]}\end{array}$ & $\begin{array}{l}<\mathrm{e}> \\
<\mathrm{e}>\end{array}$ & $\begin{array}{l}\text { 'path' } \\
\text { 'tobacco' }\end{array}$ \\
\hline (b) & $\begin{array}{l}\text { /wé̃j/ } \\
/ \text { wãj/ }\end{array}$ & $\begin{array}{l}{[\mathrm{H}]} \\
{[\mathrm{L}]} \\
\end{array}$ & $\begin{array}{l}<w u \tilde{y}> \\
<\text { ũy }>\end{array}$ & $\begin{array}{l}\text { 'port' } \\
\text { 'far' }\end{array}$ \\
\hline (c) & $\begin{array}{l}\text { líhí/ } \\
\text { /íhi/ }\end{array}$ & $\begin{array}{l}{[\mathrm{HH}]} \\
{[\mathrm{HL}]} \\
\end{array}$ & $\begin{array}{l}<\text { ihi> } \\
<\text { ihi> }\end{array}$ & $\begin{array}{c}\text { 'winter' } \\
\text { 'kind of monkey' }\end{array}$ \\
\hline (d) & $\begin{array}{l}\text { /o?át/ } \\
\text { /oPat/ }\end{array}$ & $\begin{array}{l}{[\mathrm{LH}]} \\
{[\mathrm{LL}]} \\
\end{array}$ & $\begin{array}{l}<0^{\prime} \text { at }> \\
<0^{\prime} \text { at }>\end{array}$ & $\begin{array}{l}\text { 'S/he fell.' } \\
\text { 'I fell.' }\end{array}$ \\
\hline (e) & $\begin{array}{l}\text { ládzódzót/ } \\
\text { /adzodzot/ }\end{array}$ & $\begin{array}{c}{[\mathrm{HHH}]} \\
{[\mathrm{LLL}]}\end{array}$ & $\begin{array}{l}<\text { ajojot }> \\
<\text { ajojot }>\end{array}$ & $\begin{array}{l}\text { 'grandparent' } \\
\text { 'We (incl.) came.' }\end{array}$ \\
\hline (f) & $\begin{array}{l}\text { láj/ } \\
\text { /äj/ }\end{array}$ & $\begin{array}{l}{[\mathrm{H}]} \\
{[\mathrm{L}]} \\
\end{array}$ & $\begin{array}{l}<\text { ay }> \\
<\text { ay }>\end{array}$ & $\begin{array}{l}\text { 'kind of rodent' } \\
\text { 'sloth (animal)' }\end{array}$ \\
\hline
\end{tabular}

The absence of orthographic markings leads to indistinctness of words that differ only in phonation types, as the pairs in (3a) and (3d), or tone, as in (4a-e), or both as in (4f). For native speakers, the meanings could be distinguished by syntactic and semantic contexts, but for non-speakers, Mundurukú writing and reading becomes more difficult.

Another issue is the interference of literacy skills from Portuguese to Munduruku. This is what has been happening in the state of Amazonas 
communities. "Mundurukú do Amazonas" has never had an official writing system; teachers began to casually adopt the orthography used in the state of Pará, or an adaptation of it, without specific training and sufficient knowledge of the language to correctly understand how it works. The most significant divergence between the two speech communities refers to the consonants / $d$ / and $/ \mathrm{r} /$; they are separate phonemes in the state of Pará, but they were neutralized to $/ \mathrm{r} /$ in the Amazonas variant. ${ }^{13}$ Despite of their similarity, orthographic conventions are quite divergent. An example of this is a school book containing short dialogues of daily situations, organized by Cardoso Mundurukú (1995), a local resident concerned about language loss. In the book, Cardoso Mundurukú makes use of a particular set of letters. His system, presented in [5], is based on his own perception of spoken Mundurukú, with a great deal of Portuguese influence.

[5] Alphabet of Mundurukú do Amazonas (adapted from CARDOSO MUNDURUKÚ, 1995)

\begin{tabular}{|c|c|c|c|c|c|c|c|}
\hline Vowels & \multicolumn{2}{|c|}{ Front } & Central & Back & & & \\
\hline High & $\begin{array}{l}\text { /i/ } \\
\mathrm{i}\end{array}$ & $\begin{array}{l}\mid \tilde{i} / \\
\tilde{1}\end{array}$ & & & & & \\
\hline Mid & $\begin{array}{l}\text { le/ } \\
\mathrm{e}\end{array}$ & $\begin{array}{l}|\tilde{e}| \\
\tilde{\mathrm{e}}\end{array}$ & $\begin{array}{ll}\text { le/ } & \\
+, & \text { e } / \\
\mathrm{u} & ?\end{array}$ & $\begin{array}{ll}\mathrm{o} / & \\
\mathrm{o}, & / \tilde{\mathrm{o}} / \\
\mathrm{u} & \mathrm{o} \\
\end{array}$ & & & \\
\hline Low & & & $\begin{array}{cc}\mathrm{e} & \tilde{\mathrm{e}} \\
\mathrm{la} / & / \tilde{a} / \\
\mathrm{a} & \tilde{\mathrm{a}} \\
\end{array}$ & $\mathrm{u} \quad \tilde{\mathrm{u}}$ & & & \\
\hline \multicolumn{2}{|c|}{ Consonants } & \multicolumn{2}{|c|}{ Bilabial } & Alveolar & Palatal & Velar & Glottal \\
\hline \multicolumn{2}{|l|}{ Stops } & $\begin{array}{l}/ \mathrm{p} / \\
\mathrm{p}\end{array}$ & $\begin{array}{c}\mathrm{b} / \\
\mathrm{b}\end{array}$ & $\begin{array}{c}/ \mathrm{t} / \\
\mathrm{t}\end{array}$ & \begin{tabular}{cc|}
$\mathrm{t} \int /$ & $/ \mathrm{d} /$ \\
$\mathrm{tx}$ & $\mathrm{dj}$
\end{tabular} & $\begin{array}{l}/ \mathrm{k} / \\
\mathrm{k}\end{array}$ & /P/ \\
\hline \multicolumn{2}{|l|}{ Nasals } & & $\begin{array}{c}/ \mathrm{m} / \\
\mathrm{m}\end{array}$ & $\begin{array}{c}/ \mathrm{n} / \\
\mathrm{n}\end{array}$ & & $\begin{array}{l}/ \mathrm{y} / \\
\mathrm{g}, \mathrm{ng}, \mathrm{nh}\end{array}$ & \\
\hline \multicolumn{2}{|l|}{ Fricatives } & & & $\begin{array}{l}/ \mathrm{s} / \\
\mathrm{s}\end{array}$ & $\begin{array}{l}/ S / \\
\mathrm{x}\end{array}$ & & $\begin{array}{c}\text { /h/ } \\
\mathrm{h}\end{array}$ \\
\hline \multicolumn{2}{|c|}{ Approximants } & & $\begin{array}{c}\text { /w/ } \\
\mathrm{w}\end{array}$ & $\begin{array}{c}/ \mathrm{r} / \\
\mathrm{r}\end{array}$ & $\begin{array}{l}\text { /j/ } \\
\mathrm{y}, \mathrm{i}\end{array}$ & & \\
\hline
\end{tabular}

${ }^{13}$ A 500-word list was recorded with Ms. Ester Caldeira Cardoso, one of the last speakers. A complete phonological analysis is in progress. 
The words in [6] compare Cardoso's and Crofts' written forms, followed by their respective phonemic representations.

[6]

(a)

(b) $<$ otxedj+>

(c) <utxexat>

(d) $<$ djeum $>$

(e) $<$ wuy $>$

(f) <kaypatpãn >

(g) $\quad<$ kapig $>$

(h) <nha s+ng>

\section{Crofts}

$$
<\text { onn }>
$$

$<$ oceju $>$

$<$ ocexat>

$<$ jeum $>$

$<$ wũy $>$

$<$ kaypatpan $>$

$<$ kapig̃ $>$

$<$ ğasũ $>$
Phonemic representation

\begin{tabular}{|c|c|}
\hline /ốn/ & 'I' \\
\hline lotSedzél & 'We (excl.)' \\
\hline /otféfat/ & 'Our (excl.) food' \\
\hline /ḑ3 eám/ & 'to go up' \\
\hline /wõj/ & 'far' \\
\hline /kajpátpán/ & 'to play' \\
\hline /kapín/ & 'to work' \\
\hline /yásã/ & 'now, today' \\
\hline
\end{tabular}

In Cardoso's proposal, the letters $<\mathrm{u}>$ and $<\mathrm{o}>$ are used to represent the same vowel phoneme /o/, examples (6b-c), which contain the same prefix /otse-/ '1PL.INCL'; <u> may also correspond to /ə/, as in (6d-e). For Crofts $<\mathrm{u}>$ stands for the central vowel/a/, whereas Cardoso also represents this vowel by $\langle+>$ (probably meaning [i]). Nasality is another feature that is not consistently marked in Amazonas, as shown by the examples (6a) and (6e-f). Cardoso also replaces $\langle\mathrm{c}\rangle,\langle\mathrm{j}\rangle$ by groups of letters, $\langle\mathrm{tx}\rangle,\langle\mathrm{dj}\rangle$ respectively. Other characters include $<\mathrm{nh}>,<\mathrm{ng}>$ and $<$ g $>$ for the same phoneme $/ \mathrm{y} /$, $(6 \mathrm{~g}-\mathrm{h})$; this variation is due to the phonetic variants that $/ \mathrm{y} /$ has: [n] syllableinitially, and [y] or [ $\left.{ }^{\mathrm{g}} \mathrm{y}\right]$ syllable-finally. The sequence $<\mathrm{nh}>$ is possibly due to Portuguese since it is the orthographic representation of the palatal nasal /n/ in that language.

Cardoso employs only $<\mathrm{r}>$ in his system, but the students preferred to state this dialect difference as an orthographic rule (see [10] below), maintaining a standardized writing system.

[7]

Amazonas Pará

Orthographic form

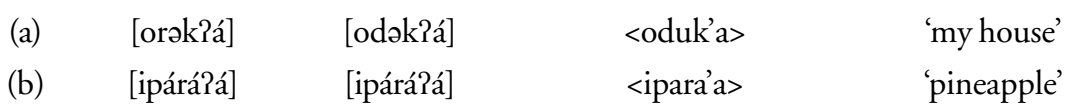

For non-speakers of Munduruku, who speak Portuguese, the writing system proposed for the Amazonas variant does not serve to the needs of language learners. In this respect, Crofts' proposal is easier and better to work with; tone and phonation markings could be useful for pronunciation purposes, but these details have not been discussed yet. The Munduruku do 
not seem to be aware of tone and never attempt to indicate it, but, particularly in the case of creaky voice, they tend to mark this laryngeal contrast with the apostrophe. The examples in [8] show various ways students write words that have creaky vowels.

[8] Variations in the Mundurukú orthography caused by creaky phonation

\begin{tabular}{|c|c|c|}
\hline /aj/ & $\left.<\mathrm{a}^{\prime} \mathrm{y}\right\rangle,<\mathrm{ay}>,<\mathrm{a}^{\prime} \mathrm{i}>,<\mathrm{ai}>,<$ hay $>$ & 'sloth (animal)' \\
\hline láj/ & $<$ ay $>,<$ ai $>,<$ hay $>$ & 'kind of rodent' \\
\hline /wida/ & $<$ wida $>$, <wi'da'>, <wi'da $>$, <wid'a $>$ & ‘jaguar’ \\
\hline /wida/ & $<$ wida $>$, < uida $>$, <wira $>$ & 'clay' \\
\hline /kąaía/ & $<$ kabia $>,<$ kabi'a $>,<$ ka'bi'a $>,<$ kabi'ya $>$ & 'day, good morning' \\
\hline /ipíl & $<$ ipi $>,<$ ' pi $>,<$ ipi'> & 'floor' \\
\hline /ipí/ & $<$ ipi $>$ & 'It hurts.' \\
\hline
\end{tabular}

It was clear that, one way or another, the Mundurukú students are aware of their orthography, but there was a need to evaluate objectively their writing skills. Moreover reading materials are already in use or in progress, reproducing the same orthographic inconsistencies as the ones previously mentioned, and more. It is urgent to find an orthographic homogeny and end these unsystematic writing practices.

To show them these inconsistencies, writing was tested in class in the following way. A list of twenty isolated words in Portuguese was presented to the students; their task was to write the corresponding forms in Mundurukú. The words, essentially common nouns (e.g. animals, plants, etc.), were all familiar to them in Munduruku; each word on the list was pronounced in Mundurukú by one of speakers from the state of Pará and they were instructed to write it without any help.

The evaluation results are partially shown in [9] below. There was not a single word in the list that was uniformly written; in fact, it is common for the word to have various orthographic forms. The problem is not restricted to the communities in Amazonas or to Mundurukú (e.g. MEIRA, 2004; FRANCHETTO, 2008; NEVINS; MOORE, 2011 etc.). A similar assessment was previously performed in the the state of Pará, with about 90 Mundurukú teachers, and the results were identical. 


\section{[9] Variations in Mundurukú orthography in Pará and Amazonas}

\begin{tabular}{|c|c|c|c|c|}
\hline Phonemes & Letters used & Examples & Orthographic forms & Gloss \\
\hline$/ \mathrm{t} \int /$ & “c, $\tilde{c}, t x, t c h, t j "$ & /datsé/ & dace, datxe, datche, datje & 'hawk' \\
\hline $\mid d z /$ & “j, dz, dj” & $/ \mathrm{da} d \dot{\sim} /$ & daje, dadze, dadje & 'peccary' \\
\hline$/ \mathrm{k} /$ & "k, c" & /kák/ & kak, cak & 'fox' \\
\hline$/ \mathrm{y} /$ & “ $\tilde{g}, \mathrm{ng}, \mathrm{nh}, \tilde{\mathrm{n}} "$ & $\begin{array}{l}\text { /tánel } \\
\text { /nõy?ál }\end{array}$ & $\begin{array}{l}\text { tag̃e, tanhẽ, tañe } \\
\text { nôg̃ a, nông'a }\end{array}$ & $\begin{array}{l}\text { 'rat' } \\
\text { 'flea' }\end{array}$ \\
\hline$/ \mathrm{w} /$ & "w, u” & /tawél & tawe, taue & 'monkey' \\
\hline$/ y /$ & “y, i” & /dajdó/ & daydo, daido, da'ido & 'armadillo' \\
\hline$/ \tilde{\mathrm{v}} /($ nasal V) & “ṽ, vn, vm” & $\begin{array}{l}\text { /okõ/ } \\
\text { /oóm/ }\end{array}$ & $\begin{array}{l}\text { okô, okom } \\
\text { oô, oôm, oom }\end{array}$ & $\begin{array}{l}\text { 'my tongue' } \\
\text { 'I came in' }\end{array}$ \\
\hline /a/ & “u, $\dot{\mathrm{i}}, \mathrm{o} "$ & /kapəsə́/ & kapusu, kaposu, kapusi & 'a bird' \\
\hline
\end{tabular}

Orthographic discrepancy is a direct consequence of the need of trained language teachers and good teaching techniques. Learning materials are rare and inadequate to instruct the most usual pronunciations of letters, letter recognition, sound-symbol correspondences etc. Most of them were unaware of basic orthographic conventions (e.g., use of $<y>$ and $<\mathrm{i}>$ ) and there are many Portuguese-based adjustments (e.g., use of $<\mathrm{c}>$ for $/ \mathrm{k} /$, or $<\mathrm{nh}>$ for $/ \mathrm{y} /$ ), often suggested by non-linguist educators.

These examples served to introduce the discussion of orthographic standardization, orthographic rules, dialectal variation, character choice, and their overall benefits and inconveniences. The students were able to analyze the inconsistencies and discuss learning problems and solutions that are important to a literacy planning. They chose to continue the use of Crofts' orthographic proposal, but agreed to include specific statements about standardized forms. The following general statements were established as a guide:

\section{[10] Orthography statements}

The Munduruku alphabet is composed of seventeen letters for consonants, $<b, c, d, h, j$, $k, m, n, \tilde{g}, p, r, s, t, w, x, y$, '>, and five letters for vowels, $\langle a, e, i, o, u>$; nasal vowels are marked by a tilde, $<\tilde{a}, \tilde{e}, \tilde{i}, \tilde{o}, \tilde{u}>$.

The glottal stop is represented by the apostrophe <'>, and it is to be used only between vowels and syllable-initially.

The letters $<d>$ and $<r>$ are both pronounced as $[\mathrm{r}]$ in our dialect.

The letters $\langle w\rangle$ and $\langle y>$ are pronounced as Portuguese $[\mathrm{u}]$ and [i], but are to be written as $\langle w\rangle$ and $\langle y\rangle$ only if they are in the same syllable with another vowel. If they are in different syllables, the letters $<o>$ and $<i>$ are to be used instead. 
The letter $\langle u>$ is not pronounced as in Portuguese [u]; it represents the vowel [a] that is similar to "o" but with unrounded lips and the tongue is forward. ${ }^{14}$

All consonants are pronounced in any position of a word, including syllable-finally.

Several activities were performed to practice the use of these orthographic norms. The students responded very well to this practice, despite their doubts about particular pronunciations (e.g. $<\tilde{g}\rangle$ and $\langle u\rangle$ ); this is because some Mundurukú sounds are different from Portuguese and will require some training.

The role of literacy in Mundurukú revitalization was a real apprehension when we began planning the revitalization program. Community members put emphasis on the importance of teaching the language in schools and learning to write it; hence literacy was a necessary component in the initial planning stages described here. As a linguist, I am more concerned with communicative abilities in the spoken language and its transmission from generation to generation. However, the school can serve to the purpose of increasing language prestige. Ultimately, it was decided that educational curriculum and written materials must emphasize culturally-based practices and verbal use and transmission of knowledge. A school curriculum will be discussed in our next meetings, which will take place in March 2012.

At the end of our meetings, various assignments were given to the students, most of them referring to the actual implementation of the present language planning. For that a Language Committee was created. It consists of a group of 15 members from different communities. Their opening responsibilities were:

- to identify all possible language resources (cultural, human, documents, etc.) available in the community;

- to implement and evaluate all actions established so far;

- to write a formal Language Planning Workbook based on all that was discussed during our meetings.

\section{Closing Remarks}

There is much more to do to complete the Munduruku language planning. Nevertheless, these preliminary stages describe important pathways headed for language revitalization in the region of Kwatá-Laranjal. On our next

${ }^{14}$ The students decided to indicate an approximate pronunciation for $\langle\mathrm{u}\rangle$ because everybody tends to read it as in Portuguese $([\mathrm{u}])$. 
meetings we will deal with the Educational Language Program, in particular with the development of curriculum and teaching materials. We are convinced that the community can overcome the barriers and acquire abilities to communicate in the native language. We also hope that sharing this endeavor may help other Brazilian indigenous groups to preserve and value their languages.

\section{References}

BELEZA, Adalberto Rodrigues. Kwatá-Laranjal: História e Reconquista da Terra. Manaus: SEDUC-AM, 2002.

BORELLA, C.; SANTOS, Eneida. A língua Mundurukú na Terra Indígena Kwatá-Laranjal: a espera do outro. In: HOLANDA, S.; PESSOA, F.; FERREIRA, M.; SARMENTO, T. (Org.). CIELLA, 3. Proceedings... v. 1, p. 217-221, 2011. BRAUN, Ilse; CROFTS, Marjorie. Mundurukú Phonology. Anthropological Linguistics, v. 7, n. 7, p. 23-39, 1965.

CARDOSO MUNDURUKÚ, Francisco. Livro de Leitura Mundurukú. Brasília; FUNAI, 1995.

CRYSTAL, David. Language Death. Cambridge: Cambridge University Press. 2000. DORIAN, Nancy C. Language death: The life cycle of a Scottish Gaelic dialect. Philadelphia: University of Pennsylvania Press, 1981.

DORIAN, Nancy C. The problem of the semi-speaker in language death. Linguistics 191, p. 23-32, 1977.

FERNANDO PALMEIRA, C. (Org.). Kwata-Laranjal, História e Reconquista da Terra. Manaus: SEDUC-AM, 2002.

FRANCHETTO, Bruna. A guerra dos alfabetos: Os povos indígenas na fronteira entre o oral e o escrito. MANA, Estudos de Antropologia Social, v. 14, n. 10, p. 31-59, 2008.

FUNASA, 2010. Sistema de Informação da Atenção à Saúde Indígena - Siasi Demografia dos Povos Indígenas. Quantitativos de pessoas. Retrieved: Dec. 26, 2011, from: <www.funasa.gov.br/internet/desai/sistemaSiasiDemografiaIndigena.asp>. GRENOBLE, L. A.; WHALEY, L. J. Saving Languages: An Introduction to Language Revitalization. New York: Cambridge University Press, 2006.

GRIMES, Barbara F. (Ed.). The Ethnologue. $14^{\text {th }}$ edition. Dallas: Summer Institute of Linguistics, 2000.

GRINEVALD, C. Language Contact and Language Degeneration. In: COULMAS, F. (Ed.). The Handbook of Sociolinguistics. Oxford - United Kingdom: Blackwell, 1997. p. 257-270. 
HINTON, Leanne. Language Planning. In: HINTON, L.; HALE, K. (Ed.). The Green Book of Language Revitalization in Practice. San Diego: Academic Press, 2001, p. 51-62.

INSTITUTO SOCIO-AMBIENTAL. Retrieved: Sep. 17, 2011, from: <http:/ /pib.socioambiental.org>.

MEIRA, Sérgio. O linguista e a ortografia indígena: o caso da língua Bakairi. Revista de Estudos e Pesquisas. Brasília: FUNAI, v. 1, n. 2, p. 73-99, 2004.

NEVINS, A. I.; MOORE, D. The repair problem: diagnostics and competing orthographic subsystems in Suruí. In: Austin, P. K., Bond, O., Marten, L., Nathan, D. (Ed.). CONFERENCE ON LANGUAGE DOCUMENTATION AND LINGUISTIC THEORY, 3. Proceedings... London: SOAS, v. 3, p. 193-198, 2011.

PICANÇO, Gessiane. Mundurukú: Phonetics, Phonology, Synchrony, Diachrony. 2005. Doctoral Dissertation - Department of Linguistics, University of British Columbia, Canada, 2005.

SANTOS, E.; BORELLA, C. Relatório do Levantamento Sociolinguistico do Povo Mundurukú. Manaus: Faculdade de Educação/UFAM, February 2011. 